UDK 629.086

\title{
OPTIMIZATION METHODS OF OPERATING COSTS ON ROAD TRANSPORT IN INTERNATIONAL TRANSPORTATION
}

\author{
S. I. Bondariev \\ National University of Life and Environmental Sciences of Ukraine, Ukraine. \\ Speciality of article: 275 - transport technologies (by road). \\ Corresponding author: bondarevgall@meta.ua.
}

Article history: Received - April 2020, Accepted-August 2020.

Bibl. 12, fig. 2, tabl. 0 .

Abstract. Transport processes research are closely related to the economic and operational performance of road transport. During planning road transportation, the most important factor is the transport services cost. Known fact that most of the transportation costs are car fuel. The share of car fuel in the transport tariff cost can be $25-50 \%$ (depending on the working conditions of vehicles). Therefore, research that is associated with improving the vehicles efficiency by reducing variable costs is appropriate and relevant. The article presents the results of research on the planning of transport processes in the road transport performance in international road transport for the return flight and calculating methods the demand for the amount of fuel purchased in different countries with different prices.

The author presents the results of theoretical and experimental research the adequacy of the mathematical model (methodology). The specified mathematical model consists in substantiation of a technique of calculation of quantity of car fuel, definition of the variable factors influencing volumes of fuel expenses, calculation of correction factors (total) received on the basis of technical and operational indicators of vehicles and the influencing factors connected with features of road transport work. . The second part of the research contains the results of the development of an algorithm development to calculate the total cost of automotive fuel, which was purchased at different prices in several countries. Thus, the main purpose of research is the task of substantiating the algorithm (mathematical model - methodology) for determining fuel costs by the criterion of the highest use of fuel in countries at the lowest prices.

Key words: international road transport, road transport, transport costs, fuel cost, transport cost planning.

\section{Introduction}

In a market economy and globalization of production, operations of enterprises involved in foreign economic activity (FEA) in the supply chain will become more widespread not only in trade but in the industrial production and especially agricultural products also.
The market shares of international transportation of finished products by road between Ukraine and its partner countries reaches over $60 \%$.

According to the reporting data of the International Road Transport Union (IRU), the distribution of cargo transportation on regular international road routes (with the participation of Ukraine) is occupied by the territories of countries: two $-25.1 \%$, three $-38.9 \%$, four $21.4 \%$, five - only $4.8 \%$ for the period 2014-2019.

This clearly means that the share of road freight transportation within three and four countries is the largest, so The scope of the research, these routes were considered.

\section{Formulation of problem}

Among the costs items in the performance of road transport costs of motor fuel is the highest among others. Therefore, to forecast transport costs, it is necessary to have such a calculation algorithm that the results are calculated with minimal deviations in certain operating conditions of rolling stock. Scientific and research work on the substantiation of methodological approaches to calculating the total fuel consumption in road transport are relevant and such that currently remain a priority research area for researchers. The main purpose of these researches is to find an algorithm that can adequately achieve the goal of the planned research.

Problems related to the calculation of fuel consumption in commercial vehicles by carriers and scientists are solved by different approaches. It is known that the total fuel consumption of a road train depends on many operational and design factors, such as engine design (efficiency), cylinder capacity and piston stroke, excess air ratio, etc. Also an important factor is the quality of fuel, which differ in density and combustion temperature. The fuel consumption is influenced by the operating conditions - the quality of the hard road surface, terrain, speed of traffic, seasonal factors, the use of additional equipment, the own weight of the cargo and the equipped weight of trailers.

The vast majority of factors influencing fuel consumption are controlled and have small deviations of up 
to $2 \%$. But uncontrolled factors such as road and weather conditions, driver qualifications cannot be predicted and taken into account in algorithms with a certain probability, is deviations from the basic indicators.

The share of the road transport market in international traffic between Ukraine and its economic partners reaches $60 \%$. Volumes of cargo are transported by road through the territory, mainly 2, 3, 4 countries. Taking into account the passage of international routes on the territory of 3 and 4 countries is the largest, so these studies are performed for the specified conditions of the routes.

\section{Analysis of recent research results}

Fuel consumption rates and motor oil in road transport are regulated by the order of the Ministry of Transport of Ukraine dated February 10, 1998 N 43 with the latest changes of the Ministry of Infrastructure of Ukraine by order dated January 24, 2012 N 36. In practice, fuel consumption rates may differ - may be higher or lower depending on the influence of a complexity of subjective and objective factors [1-12].

The paper analyzes research on the calculation of fuel consumption. We pay special attention to the works devoted to the search for adequate mechanisms to increase fuel efficiency in the operation of vehicles, calculating fuel consumption in road transport depending on different operating conditions, using experimental, statistical and analytical models [2-9]. The authors [2-6] hold the view that analytical techniques have an advantage over experimental in terms of natural causes and are rational for practical use by workers in the automotive industry. Another approach is analytical-experimental, adopted for the conditions of research $[5,6,8]$. In the works of researchers, a common approach to optimizing fuel efficiency in the performance of transportation is the selection of vehicles with appropriate parameters and, based on this, adapt analytical techniques for calculating fuel consumption $[2,6,7,9]$.

The algorithm for determining fuel consumption can be set directly for the operation of a particular rolling stock with the maximum approximation. However, there are operational factors that cannot be predicted with high accuracy, so the analytical dependences introduced correction factors [2-9]. Correction factors are best determined using statistical research methods and then introduced into the method of calculating fuel consumption, process maps, accounting programs, etc. [6-8].

A review of recent studies has concluded that the calculation of fuel consumption for the operating conditions of the car company should be determined by an algorithm that takes into account the technical characteristics of the car (rolling stock) and a number of influencing factors with mandatory determination of adjustment factors experimentally.

\section{Purpose of research}

In order to ensure adequate forecasting of fuel consumption in the performance of international road transport, it is planned to theoretically substantiate the model and experimentally test it in operating conditions, namely: to perform research to determine the amount of fuel consumption on the route; experimentally confirm the adequacy of models to determine the amount of fuel consumption; determine the conditions for the distribution of prices by country of the route; analytically determine fuel costs by the criterion of their minimum prices on the route.

\section{Results of research}

The author analyzes a multiple research devoted to the search for adequate methods for determining fuel consumption in road transport, directly experimental, statistical and analytical. Most authors are of the opinion that analytical techniques have an advantage in terms of natural causes and are rational for practical use by workers in the automotive industry $[1,2]$. Another approach is analytical and experimental.

The essence of this approach is the adaptation of the analytical model to the experimental research results of fuel consumption. The experimental part is based on obtaining reliable cost data by installing special measuring equipment flow, mechanical, pulse and reciprocally incorporated (mechanical recorders + remote pulse waveforms) flow meters, as well as the so-called fuel-air receivers, which are widely available of different manufacturers on the market today.

The results of the research are processed by engineers and adjustments are made to the values of the elements of the adjustment factor. Therefore, the experimental part of our research to determine fuel consumption, we conducted using a car/fuel log DFM 100D. The basis of the car/fuel log DFM 100 D measuring volume chamber of the ring type. When the fuel flows, the sensor begins to generate a pulse that will be equal to the volume of the measuring chamber. It can be used both autonomously and as a part of GPS / GLONASS systems of monitoring of transport and control of fuel consumption. In research, the car/fuel log worked autonomously.

Every engineer, manager, logistician must know not only the technical and operational parameters of rolling stock, but also the specifics of freight conditions in which the company specializes and take into account the particularities, calculating the adjustment factor for selected operating conditions and routes [2]. In terms of scientists, it is possible to solve a multicriteria problem with many different factors that accompany the transport process, but with a fairly approximate result, in the universalization of these processes is not accurate. Therefore, there is an individual approach, which we have chosen for research.

Due to researches it is established, that the classic, proven in practice analytical model for calculating the total cost of automotive fuel on the selected route is fully suitable for achieving this goal. Therefore, the calculation of total fuel consumption Qzag define:

$$
Q_{\text {tot }}=\left(\frac{Q_{\text {Lan }}}{100} \cdot l_{\text {tot }}+\frac{Q_{W}}{100} \cdot W\right) \cdot k_{a}
$$

where $1_{\text {tot }}$ - total mileage on the route, $\mathrm{km} ; \mathrm{Q}_{\mathrm{W}}$ - additional specific fuel consumption rate per 100 ton $\mathrm{km}$; W - performed amount of transport work, $\mathrm{t} \cdot \mathrm{km}$; 


$$
W=Q_{\mathrm{c}} \cdot l_{\text {tot }}, \mathrm{t} \cdot \mathrm{km} ;
$$

where $Q_{\mathrm{c}}$ - weight of transported cargo, ton; $\mathrm{Q}_{\mathrm{Lan}}$ - linear rate of fuel consumption for the mileage of the road train:

$$
\mathrm{Q}_{\mathrm{Lan}}=\mathrm{Q}_{\mathrm{L}}+\mathrm{Q}_{\mathrm{W}} \cdot \mathrm{G}_{\mathrm{st}}, \mathrm{l} / 100 \mathrm{~km}
$$

where $\mathrm{Q}_{\mathrm{L}}$ - basic linear rate of fuel consumption, $1 / 100 \mathrm{~km} ; \mathrm{G}_{\mathrm{st}}$ - equipped weight of the semi-trailer, ton; $\mathrm{k}_{\mathrm{K}}$ - adjustment coefficient.

The correction coefficient is the average value obtained from the results of experimental measurements with DFM 100 D. The results of the research were constructed through highlight the influence of certain main influencing factors (for example, such as the average speed of vehicles; road conditions (route specificities), seasonality, weight of the transported cargo and much more) on the additional fuel consumption on the route. The obtained of fuel consumption by factor research were summed up and included in the total correction factor $\left(\mathrm{k}_{\mathrm{a}}\right)$.

To calculate the fuel consumption of trucks on sections of the pendulum route in both directions, it is necessary to determine the cost per kilometer passed way, and therefore we have get in general terms:

$$
Q_{t o t(k m)}=\left(\frac{Q_{L a n}}{100}+\frac{Q_{W(\mathrm{~km})}}{100} \cdot G_{c}\right) \cdot k_{a}, \mathrm{~L} / \mathrm{km}
$$

Given the restrictions on the import of fuel into the countries of the route, the limitation of the standard tank vehicle volume (standard, manufacturers), determine the conditions of refueling in the countries of the route, depending on its cost. The main goal is to refuel the vehicle in such a way as to maximize the use of fuel at a lower cost.

Let's draw a pendulum route through the territory of three countries in the form of vector graphics (Fig. 1).

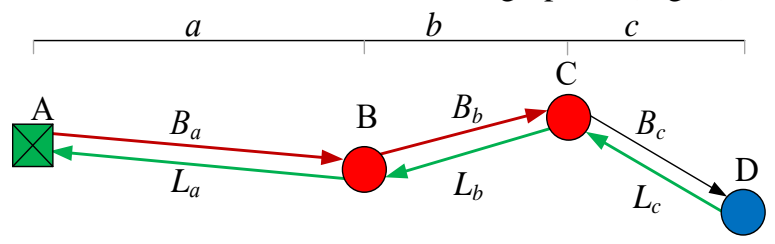

Fig. 1. Scheme of the pendulum route in the form of unified vectors. A - point of departure; D - point of arrival; $\mathrm{B}$ and $\mathrm{C}$ - customs checkpoints at the borders of neighboring countries; $\mathrm{a}, \mathrm{b}, \mathrm{c}$ - the countrys of passage of the route; $\mathrm{Va}, \mathrm{Vb}, \mathrm{Vc}$ - cost of fuel by countries of routes; La, Lb, $\mathrm{Lc}$ - the distance of the route through the countries of the route.
The next task of the research was to determine the conditions of fuel price distribution in the countries of the route. We present the conditions as follows:

1) $\mathrm{Ba}<\mathrm{Bb}<\mathrm{Bc}$;

2) $\mathrm{Ba}>\mathrm{Bb}>\mathrm{Bc}$

3) $\mathrm{Ba}<\mathrm{Bb}>\mathrm{Bc}$; при Ва $>\mathrm{Bc}$;

4) $\mathrm{Ba}<\mathrm{Bb}>\mathrm{Bc}$; при $\mathrm{Ba}<\mathrm{Bc}$.

5) $\mathrm{Ba}>\mathrm{Bb}<\mathrm{Bc}$; при $\mathrm{Ba}>\mathrm{Bc}$;

6) $\mathrm{Ba}>\mathrm{Bb}<\mathrm{Bc}$; при $\mathrm{Ba}<\mathrm{Bc}$.

For further calculations, the initial data are: fuel consumption in the forward and reverse directions per one $\mathrm{km}$; distances by countries of the route; standard tank capacity; the minimum technological stock of fuel in a tank. In practice, to determine fuel consumption by the criterion of the minimum price in the countries of the route can be a specialist "manually". therefore, drawing up a scheme of the route, calculating the fuel cost by country depending on the distance traveled, taking into account the fuel cost by country of passage of the route and then the scheme of minimization. The result of such calculations is a recommended table (place) of refueling vehicles with the exact indication of the fuel volume before or outside the customs borders of countries and at intermediate refueling points.

We conducted a full cycle of analytical research to calculate the cost of international transportation in three and four countries under all possible conditions of the distribution of fuel prices in the countries of the route. The obtained results were appropriately processed, checked for adequacy and entered in the form of appropriate algorithms into the computer program Microsoft Excel, which performs the necessary calculations in a split second for all possible options (Fig. 2).

To achieve this goal, Microsoft Excel was chosen for the reason that this program is on any PC. The set purpose of researches is executed in full, and the analytical model on definition of expenses of means for performance of the international routes, under various conditions of distribution of the prices on the countries, on criterion of their minimization, is realized in the computer program Microsoft Excel not only for scientific purposes, but for practical use at car companies and logistics organizations also.

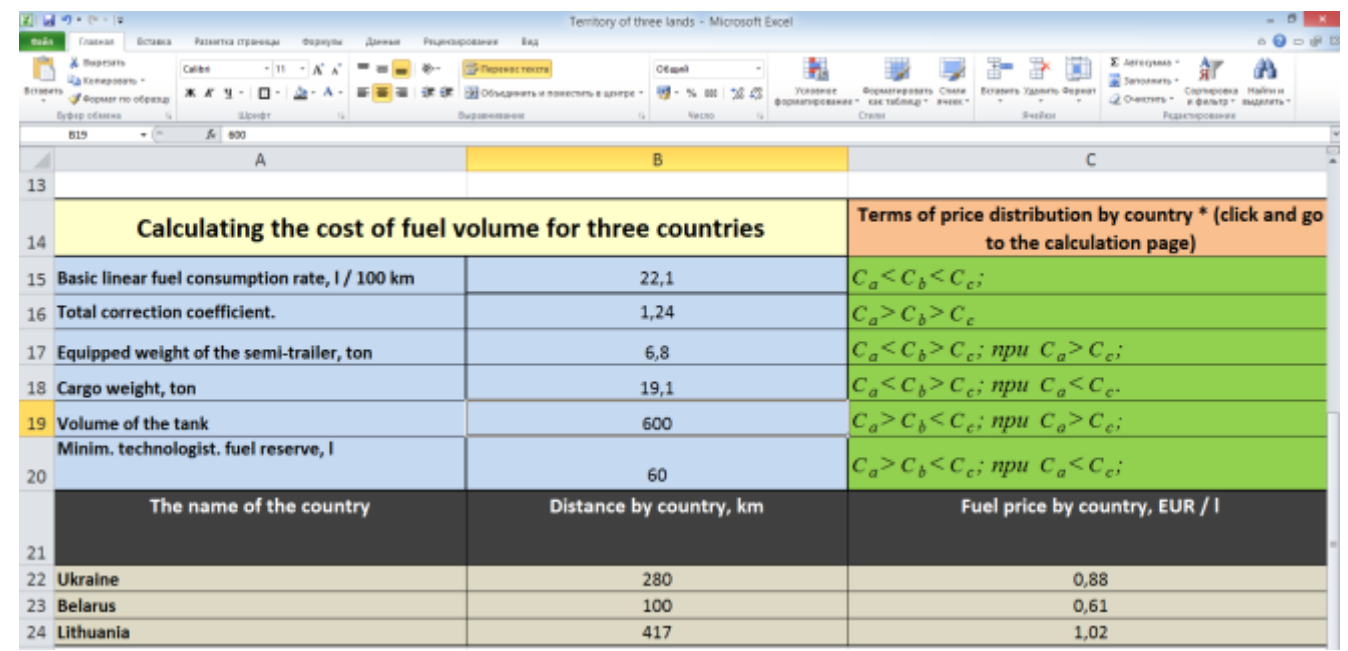

Fig. 2. View of the main page window with the initial data of the program for determining fuel costs by the criterion of using fuel with a minimum price for international transportation through the territory of three countries. 
Thus, the article substantiates the analytical mathematical algorithm for determining the minimum cost of fuel, in the implementation of the international pendulum flight, on the criterion of maximum use of its volume with the minimum price in the countries of the route.

\section{Conclusions}

1. Research substantiates and confirms the effectiveness of adequate methods for calculating fuel consumption in road transport.

2 . The conditions of modification of the price distribution by the countries of the route are determined in order to substantiate the algorithm for determining the minimum fuel costs in the implementation of the international road pendulum route.

3. Analytically substantiated and tested in practice the algorithm for determining the minimum fuel consumption in the implementation of the international pendulum flight, taking into account the difference in fuel prices by country of route.

\section{References}

1. Sharay S. M. (1990). Estimation of fuel economy of cars with use of statistical characteristics of road conditions: author's ref. dis. at the request of scientists. stepenny cand. tech. Science: special. 05.05.03. Kyiv: KHI, 21.

2. Kuzmin N. A. (2010). The problem of rationing the consumption of automotive fuel and lubricants in the RF. Motor Transport Enterprise. № 8. 20-22.

3. About the statement of Norms of expenses of fuel and lubricants on motor transport. (2020). Electronic resource. the Order of the Ministry of Transport from 10.02.1998 №43. Access mode: । www / URL: http://dtkt.com.ua/documents/ukr/2012/08/9289.html/ Title. from the screen.

4. Ilchenko A. V. (2003). Increasing the efficiency of car operation using motor fuels with high-octane oxygen-containing additives: dis. ... cand. tech. Kyiv. 212.

5. Sahno V. P., Bezborodova G. B., Mayak M. M., Sharai S. M. (2004). Cars. Traction-speed properties and fuel economy: Textbook. manual. Kyiv. In the "Kvits", 174.

6. Slavin V. V. (2012). Influence of type of power supply system on indicators of fuel economy of cars. Problems of transport: collection. 9. 198-201.

7. Kuzmin N. A. (2010). The problem of rationing the consumption of automotive fuels and lubricants in the Russian Federation. Motor transport enterprise. 8. 20-22.

8. Plekhanov D. K., Kuzmin N. A. (2009). Strategies for dispatch control of the work of trucks during mass transportation. Motor transport enterprise. 12. 40-41.

9. Grabar I. G., Ilchenko A. V. (2001). Software and hardware complex for the study of the kinetics of fuel consumption. Bulletin of KSADTU. 15(16). 163-165.

10. Equipment and solutions for monitoring fuel consumption. (2020). Access mode: I www / URL: http://technoton.cartuning.avers-c.com.ua. Title. from the screen.

11. Zagurskiy O., Rogach S., Titova L., Rogovskii I., Pokusa T. (2019). «Green» supply chain as a path to sustainable development. Mechanisms of stimulation of socio-economic development of regions in conditions of transformation. Monograph. Opole: The Academy of Management and Administration in Opole. 199-213.

12. Zagurskiy O., Ohiienko M., Pokusa T., Zagurska S., Pokusa F., Titova L., Rogovskii I. (2020). Study of efficiency of transport processes of supply chains management under uncertainty. Monograph. Opole: The Academy of Management and Administration in Opole. 162.

\section{Список літератури}

1. Sharay S. M. Estimation of fuel economy of cars with use of statistical characteristics of road conditions: author's ref. dis. at the request of scientists. stepenny cand. tech. Science: special. 05.05.03. Kyiv: KHI, 1990. 21 p.

2. Kuzmin N. A. The problem of rationing the consumption of automotive fuel and lubricants in the RF. Motor Transport Enterprise. 2010. № 8. P. 20-22.

3. About the statement of Norms of expenses of fuel and lubricants on motor transport. 2020. Electronic resource. the Order of the Ministry of Transport from 10.02.1998 №43. Access mode: । www / URL: http://dtkt.com.ua/documents/ukr/2012/08/9289.html/ Title. from the screen.

4. Ilchenko $A$. $V$. Increasing the efficiency of car operation using motor fuels with high-octane oxygencontaining additives: dis. ... cand. tech. Kyiv. 2003. 212 p.

5. Sahno V. P., Bezborodova G. B., Mayak M. M., Sharai S. M. Cars. Traction-speed properties and fuel economy: Textbook. manual. Kyiv. In the "Kvits", 2004. $174 \mathrm{p}$.

6. Slavin $V$. $V$. Influence of type of power supply system on indicators of fuel economy of cars. Problems of transport: collection. 2012. Vol. 9. P. 198-201.

7. Kuzmin N. A. The problem of rationing the consumption of automotive fuels and lubricants in the Russian Federation. Motor transport enterprise. 2010. Vol. 8. P. 20-22.

8. Plekhanov D. K., Kuzmin N. A. Strategies for dispatch control of the work of trucks during mass transportation. Motor transport enterprise. 2009. Vol. 12. P. 40-41.

9. Grabar I. G., Ilchenko A. V. Software and hardware complex for the study of the kinetics of fuel consumption. Bulletin of KSADTU. 2001. Vol. 15(16). P. 163-165.

10. Equipment and solutions for monitoring fuel consumption. 2020. Access mode: I www / URL: http://technoton.cartuning.avers-c.com.ua. Title. from the screen.

11. Zagurskiy O., Rogach S., Titova L., Rogovskii I., Pokusa T. «Green» supply chain as a path to sustainable development. Mechanisms of stimulation of socio-economic development of regions in conditions of transformation. Monograph. Opole: The Academy of Management and Administration in Opole. 2019. P. 199-213. 
12. Zagurskiy O., Ohiienko M., Pokusa T., Zagurska S., Pokusa F., Titova L., Rogovskii I. Study of efficiency of transport processes of supply chains management under uncertainty. Monograph. Opole: The Academy of Management and Administration in Opole. 2020. 162 p.

\section{МЕТОДИ ОПТИМІЗАЦІЇ ЕКСПЛУАТАЦЙНИХ ВИТРАТ НА АВТОМОБЛЛНОМУ ТРАНСПОРТІ ПРИ МІЖНАРОДНИХ ПЕРЕВЕЗЕННЯХ

$$
\text { С. І. Бондарєв }
$$

Анотація. Дослідження транспортних процесів тісно пов'язані з економічними й експлуатаційними показниками роботи автомобільного транспорту. При плануванні автоперевезень найбільш важливим фактором є вартість транспортної послуги. Відомо, що найбільша частина транспортних витрат $\epsilon$ автомобільне пальне. У вартості транспортного тарифу частка автомобільного пального може складати 25-50 \% (в залежності від умов роботи транспорту). Тому дослідження, які пов'язані з підвищенням ефективності роботи автотранспорту за рахунок скорочення перемінних витрат $\epsilon$ доцільним і актуальним. У статті наведені результати досліджень 3 планування транспортних процесів при виконанні автоперевезень у міжнародному сполученні за оборотний рейс і методи розрахунку потреби кількості пального, яке придбали в різних країнах з різною ціною.

Автором представлені результати виконаних теоретичних досліджень та експериментально перевірено адекватність математичної моделі (методики). Вказана математична модель полягає у обгрунтуванні методики розрахунку кількості пального, визначення варіативних факторів, що впливають на обсяги витрат на пальне, розрахунок коригувальних коефіцієнтів (сумарних), отриманих на основі технічних і експлуатаційних показників автомобілів та впливових факторів, що пов'язані з особливостями роботи автотранспорту. Друга частина досліджень містить результати розробки алгоритму, призначеного для обчислення сумарних витрат коштів на автомобільне пальне, яке було придбане за різною ціною в декількох країнах. Отже головною метою досліджень є задача, що полягає у обгрунтуванні алгоритму (математичної моделі - методики) з визначення витрат на пальне за критерієм найбільшого використання пального в країнах за найменшими цінами.

Ключові слова: міжнародні автоперевезення, перевезення автотранспортом, транспортні витрати, вартість пального, планування транспортних витрат.

\section{МЕТОДЫ ОПТИМИЗАЦИИ ЭКСПЛУАТАЦИОН- НЫХ ЗАТРАТ НА АВТОМОБИЛЬНОМ ТРАНСПОРТЕ ПРИ МЕЖДУНАРОДНЫХ ПЕРЕВОЗКАХ \\ С. И. Бондарев}

Аннотация. Исследование транспортных процессов тесно связаны с экономическими и эксплуатационными показателями работы автомобильного транспорта. При планировании перевозок наиболее важным фактором является стоимость транспортной услуги. Известно, что большая часть транспортных расходов является автомобильное топливо. В стоимости транспортного тарифа доля автомобильного топлива может составлять $25-50 \%$ (в зависимости от условий работы транспорта). Поэтому исследования, связанные с повышением эффективности работы автотранспорта за счет сокращения переменных расходов целесообразны и актуальны. В статье приведены результаты исследований по планированию транспортных процессов при выполнении автомобильных перевозок в международном сообщении за оборотный рейс и методы расчета потребности количества топлива, которое приобрели в разных странах за разными ценами.

Автором представлены результаты выполненных теоретических исследований и экспериментально проверено адекватность математической модели (методики). Указанная математическая модель заключается в обосновании методики расчета количества топлива, определения сменных факторов, влияющих на объемы расходов топлива, корректирующих коэффициентов (суммарных), полученных на основе технических и эксплуатационных показателей автомобилей и влиятельных факторов, связанных с особенностями работы автотранспорта. Вторая часть исследований содержит результаты разработки алгоритма, предназначенного для вычисления суммарных затрат средств на автомобильное топливо, которое было приобретено по разной цене в нескольких странах. Поэтому главной целью исследований является задача, которая заключается в обосновании алгоритма (математической модели - методики) по определению суммы по критерию наибольшего использования объема топлива в странах где его цена наименьшая.

Ключевые слова: международные автоперевозки, перевозки автотранспортом, транспортные расходы, стоимость горючего, планирование транспортных расходов.

С. І. Бондарєв ORCID 0000-0002-9626-6633. 
